\title{
Penggunaan Model Pembelajaran Learning Cycle 5e untuk Meningkatkan Hasil Belajar Fisika Kelas VIII SMP Negeri 14 Palu
}

\author{
Syaidah, Kamaluddin dan Syamsu \\ e-mail: Syaidah.ayda91@gmail.com \\ Program Studi Pendidikan Fisika FKIP Universitas Tadulako \\ Jl. Soekarno Hatta Km. 9 Kampus Bumi Tadulako Tondo Palu - Sulawesi Tengah
}

\begin{abstract}
Abstrak - Penelitian tindakan kelas ini bertujuan untuk meningkatkan hasil belajar fisika siswa kelas VIII SMP Negeri 14 Palu. Masalah yang diteliti adalah rendahnya hasil belajar siswa pada mata pelajaran Fisika. Alternatif pemecahan masalah adalah penggunaan model pembelajaran Learning Cycle 5E. Subyek penelitian adalah siswa kelas VIII SMP Negeri 14 Palu, dengan jumlah siswa 25 orang. Penelitian ini menggunakan Penelitian Tindakan Kelas yang dilaksanakan secara bersiklus dan mengacu pada desain penelitian dari model Kemmis \& Mc. Taggart, yang meliputi 4 tahap: (i) perencanaan, (ii) pelaksanaan tindakan, (iii) observasi dan (iv) refleksi. Jenis data yang diperoleh adalah data kualitatif dan data kuantitatif. Data kualitatif adalah data yang diperoleh dalam kegiatan belajar mengajar berupa observasi dan wawancara. Hasil observasi aktivitas siswa dan guru pada siklus I berkategori cukup sedangkan siklus II berada pada kategori baik. Data kuantitatif adalah data hasil belajar yang diperoleh dengan tes. Hasil belajar siklus I diperoleh ketuntasan belajar klasikal $72 \%$ dan pada siklus II Ketuntasan belajar klasikal dan daya serap klasikal yang diperoleh pada siklus II telah memenuhi pada indikator kinerja 75\%. Berdasarkan hasil tersebut dapat disimpulkan bahwa dengan penggunaan model pembelajaran Learning Cycle 5E dapat meningkatkan hasil belajar siswa pada siswa kelas VIII SMP Negeri 14 Palu.
\end{abstract}

Kata kunci :, Learning Cycle 5e, Hasil Belajar Fisika

\section{PENDAHULUAN}

Pendidikan merupakan modal utama untuk kemajuan suatu bangsa, dewasa ini telah banyak upaya yang dilakukan pemerintah dalam hal ini Kementerian Pendidikan dan Kebudayaan untuk meningkatkan kualitas pendidikan, diantaranya adalah penyempurnaan kurikulum, mengadakan pelatihan tenaga kerja, pengadaan sarana dan pra sarana yang memadai dan masih banyak lagi kebijakan yang ditetapkan pemerintah dengan maksud untuk meningkatkan mutu pendidikan [1].

Pelaksanaan pembelajaran di dalam kelas merupakan salah satu tugas utama guru dan pembelajaran dapat diartikan sebagai kegiatan yang ditujukan pada siswa. Dalam proses pembelajaran masih sering ditemui adanya kecenderungan meminimalkan keterlibatan siswa. Dominasi guru dalam proses pembelajaran menyebabkan kecenderungan siswa lebih bersifat pasif sehingga mereka lebih banyak menunggu sajian guru daripada mencari dan menemukan sendiri pengetahuan, keterampilan atau sikap yang mereka butuhkan. Kondisi ini tidak akan menumbuh kembangkan aspek kemampuan dan aktivitas siswa yang diharapkan. Sesuai dengan observasi awal diSMP Negeri 14 Palu,didapatkan data rata-rata hasil belajar fisika siswa kelas VIII masih rendah. Hal ini disebabkan oleh pembelajaran masih berorientasi pada guru. Proses belajar mengajar pada umumnya guru hanya menggunakan metode ceramah. Oleh karena itu,peneliti menduga bahwa penyampaian materi yang cenderung monoton dan tidak mengaktifkan siswa tersebut menyebabkan rendahnya hasil belajar fisika.

Sesuai dengan observasi yang dilakukan, kondisi pembelajaran fisika masih belum memuaskan dalam hal ini sering kali terjadi keluhan. Siswa menganggap bahwa pelajaran fisika adalah pelajaran yang sulit dan susah dimengerti. Faktor lain yang menyebabkan rendahnya hasil belajar ialah siswa kurang berinteraksi pada saat kegiatan pembelajaran, cepat melupakan materi yang diajarkan, kesulitan mengembangkan ide serta menggali pikirannya sendiri. Hal ini dapat dilihat dari hasil belajar siswa SMP Negeri 14 Palu tahun 2014-2015. Seperti yang tunjukan pada tabel.

Tabel 1. Hasil Belajar Fisika Siswa SMP Negeri 14 Palu Tahun 2014-2015.

\begin{tabular}{llcc}
\hline No. & Kelas & Semester Ganjil & Semester Genap \\
\hline 1. & VIII A & 68,12 & 68,38 \\
2. & VIII B & 67.85 & 68,00 \\
3. & VIII C & 68,86 & 69,75 \\
\hline
\end{tabular}


p-ISSN 2338-3240, e-ISSN 2580-5924

Hasil tersebut menunjukan bahwa upaya pembelajaran fisika pada siswa SMP Negeri 14 Palu belum mencapai ketuntasan kelas minimal yang dipersyaratkan KKM 75,00. Mengatasi permasalahan tersebut maka model pembelajaran yang tepat diterapkan adalah model Learning Cycle 5E. Model pembelajaran ini berpusat pada siswa, proses pembelajaran menjadi lebih bermakna karena mengutamakan pengalaman nyata, dan membentuk siswa menjadi aktif, kritis, dan kreatif. Selain itu model Learning Cycle merupakan salah satu model yang memberikan kesempatan kepada siswa untuk mengoptimalkan cara belajar dan mengembangkan daya nalar siswa.

Menerapkan model Learning Cycle 5E diharapkan pembelajaran akan lebih optimal, efektif dan bermakna sehingga hasil belajar fisika siswa dapat dicapai dengan baik. Untuk lebih mengoptimalkan proses pembelajaran dengan model Learning Cycle .

\section{METODE PENELITIAN}

Adapun jenis penelitian ini merupakan penelitian tindakan kelas (classroom action research) yaitu penelitian yang dilakukan dengan penekanan pada penyempurnaan atau peningkatan proses dan praktis pembelajaran. PTK berfokus pada kelas atau pada proses belajar mengajar yang terjadi di kelas.

Penelitian ini dilaksanakan bersiklus yang mengacu pada model Kurt Lewin yang dikembangkan oleh Kemmis dan Mc.Taggart (Mulyatiningsih, 2013) yang meliputi empat kegiatan utama yang ada pada setiap siklus yaitu: (1) perencanaan (2) pelaksanaan tindakan (3) observasi dan (4) refleksi. Penggunaan model ini dikarenakan alur yang digunakan cukup sederhana dan mudah untuk dilaksanakan. Berikut adalah gambar alur pelaksanaan tindakan yang dimaksud.

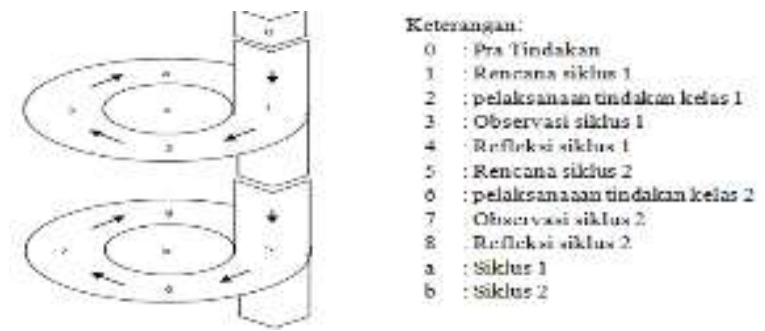

Gbr. Diagram Alur Desain Penelitian

Pada kegiatan ini peneliti berkolaborasi dengan rekan guru yang bertindak sebagai observer. Pada langkah reflecting, peneliti mengkaji, melihat dan mempertimbangkan hasil atau dampak dari tindakan yang dilakukan berdasarkan lembar pengamatan yang diisi oleh pengamat. Rancangan/rencana untuk sikus berikutnya direvisi berdasarkan hasil refleksi dari pengamat dan dipergunakan pada siklus berikutnya sehingga diharapkan memperoleh hasil yang lebih baik.

Peserta didik sebelum mendapatkan perlakuan dalam pembelajaran pada siklus I diadakan penilaian melalui tes berupa tes pratindakan, dan siswa yang sudah mendapatkan perlakuan dalam pembelajaran pada siklus I diadakan penilaian melalui tes berupa tes hasil belajar siklus I

Jenis data yang didapatkan dalam penelitian ini adalah data kuantitatif dan data kualitatif.

Sumber data dalam penelitian ini adalah gurundan siswa. (1) data yang diperoleh dari guru berupa data hasil observasi saat proses pembelajaran berlangsung; (2) data yang diperoleh dari siswa berupa hasil observasi dan hasil tes evaluasi belajar siswa.

Aktivitas siswa, yang dapat dinilai adalah aspek afektif, aspek psikomotor sedangkan aktivitas guru, alat ukur yang digunakan yaitu lembar observasi yang telah disediakan. Ketika dilakukan pengamatan terhadap aktivitas siswa dan aktivitas guru. pada saat kegiatan pembelajaran sedang berlangsung. Adapun angket diberikan kepada siswa bertujuan untuk untuk mengetahui kesulitan yang dialami oleh siswa pada saat mengikuti proses pembelajaran.

Indikator kualitatif pembelajaran dapat dilihat dari aktivitas siswa dan pengelolaan pembelajaran oleh guru, dan hasil analsisis terhadap penilaian afektif, psikomotor siswa. Penelitian ini dinyatakan berhasil jika kualitas hasil belajar untuk aspek yang dinilai tersebut telah berada dalam kategori baik atau sangat baik, serta angket respon siswa menunjukkan bahwa siswa senang dengan model pembelajaran yang diterapkan.Indikator keberhasilan penelitian tindakan ini apabila persentase daya serap individual dan ketuntasan klasikal memperoleh nilai minimal $70 \%$ serta $85 \%$ siswa senang

\section{HASIL PENELITIAN DAN PEMBAHASAN}

Kegiatan awal dilakukan sebelum Siklus I dilaksanakan adalah memberikan tes pendahuluan. Tes ini bertujuan untuk membagi siswa kedalam kelompok kooperatif yang heterogen. Adapun dua jenis data yang diperoleh dan dinilai yaitu data kualitatif dan data kuantitatif. Data kualitatif meliputi: aktivitas siswa dan guru, afektif dan psikomotor siswa. Hasil yang diperoleh pada penelitian 
p-ISSN 2338-3240, e-ISSN 2580-5924

dalam 2 siklus diperoleh seperti terlihat pada Tabel 2.

Tabel 2. Presentase aktivitas siswa dan guru

\begin{tabular}{lccc}
\hline No. & Aktivitas & \multicolumn{2}{c}{ Presentase Skor } \\
\cline { 3 - 4 } & & Siklus I & SiklusII \\
\hline 1. & Siswa & $71,25 \%$ & \\
& $87,50 \%$ & & \\
2. & Guru & $77,50 \%$ &
\end{tabular}

\section{1) Aktivitas Siswa}

Hasil analisis aktivitas siswa pada siklus I berada dalam kategori cukup dan siklus II berada dalam kategori baik. Sehingga disimpulkan bahwa aktivitas siswa pada siklus II mengalami peningkatan. Hal Ini disebabkan oleh kekurangan-kekurangan pada siklus I dapat diminimalisir dan diperbaiki pada siklus II. Selama proses pembelajaran memberi peluang untuk mendiskusikan masalah yang dihadapi, saling tukar ide antar siswa, dan memperdebatkan alternatif pemecahan masalah. Selain itu, siswa dimungkinkan mampu menyelesaikan masalah yang lebih baik dibanding jika mereka bekerja sendiri [2].

Adapun kekurangan pada siklus I, siswa tidak memberikan pendapat serta pertanyaan mengenai manfaat pengetahuan dan pengalaman untuk menggali pengetahuan baru, akibatnya siswa tidak mampu menuliskan contoh informasi tentang bagaimana memanfaatkan pengalaman belajar. Hal ini sebabkan karena kegiatan Learning Cycle $5 E$ yang diterapkan belum dipahami secara keseluruhan, sehingga siswa belum berani dalam mengeluarkan pendapat. Disamping itu, ketelitian dan keterampilan siswa pada saat pengamatan masih sangat kurang, hal ini disebabkan oleh sebagian siswa masih kurang termotivasi untuk melibatkan dirinya dalam kegiatan selama pembelajaran.

\section{2) Aktivitas Guru}

Hasil analisis aktivitas guru pada siklus I berada dalam kategori baik dan siklus II berada dalam kategori sangat baik . Sehingga disimpulkan bahwa aktivitas siswa pada siklus II mengalami peningkatan. Hal Ini disebabkan oleh kekurangan-kekurangan pada siklus I dapat diminimalisir dan diperbaiki pada siklus II. Berdasarkan penelitian sebelumnya bahwa guru dalam mengelolah dalam memilih model maupun metode pembelajaran yang tepat bagi siswa, dan dapat mengaktifkan siswa dalam setiap pembelajaran berlangsung. Salah satu alternatif model pembelajaran yang berbasis pada siswa yaitu model pembelajaran Learning Cycle 5E.

Peningkatan hasil belajar yang terjadi pada siklus I ke siklus II dikarena siswa lebih senang dalam proses pembelajaran dengan penggunaan model pembelajaran Learning Cycle 5E dengan dibantu bimbingan guru, sehingga siswa lebih mudah mengingat dan memahami materi yang diajarkan.

\section{3) Penilaian Afektif}

Penilaian sikap dilakukan pada saat pembelajaran sedang berlangsung. Pada siklus I , keaktifan siswa masih belum terlihat. Hal ini dikarenakan siswa belum terbiasa dengan model pembelajaran learning cycle 5E. Pada siklus II, siswa mulai aktif dalam proses pembelajaran. Hal ini karena siswa telah mengetahui langkah-langkah yang mereka kerjakan. Selain itu, siswa telah terbiasa untuk mengemukakan pertanyaan, pendapat dan menjawab pertanyaan yang diajukan, serta memiliki inisiatif untuk terlibat langsung dalam kegiatan yang dilakukan selama proses pembelajaran. Hasil penilaian afektif siswa dapat dilihat pada tabel 3 .

Tabel 3. Presentase nilai efektif siswa

\begin{tabular}{|c|c|c|c|c|}
\hline \multirow[t]{2}{*}{ No } & \multirow{2}{*}{\multicolumn{2}{|c|}{ Siklus }} & \multicolumn{2}{|c|}{ Presentase } \\
\hline & & & $\begin{array}{l}\text { Skor } \\
\text { rata }\end{array}$ & Rata - \\
\hline 1. & Siklus 1 & $\begin{array}{l}\text { Pertemuan I } \\
\text { Pertemuan II }\end{array}$ & $\begin{array}{l}77,76 \% \\
80,32 \%\end{array}$ & $79,04 \%$ \\
\hline 2. & Siklus 2 & $\begin{array}{l}\text { Pertemuan I } \\
\text { Pertemuan II }\end{array}$ & $\begin{array}{l}82,72 \% \\
90,08 \%\end{array}$ & $86,40 \%$ \\
\hline
\end{tabular}

\section{4) Penilaian Psikomotor}

Aktivitas psikomotor siswa pada siklus I berada kategori kurang dan Pada siklus II berada kategori baik. Peningkatan ini karena Kinerja dari masing-masing siswa dalam kelompok meningkat disetiap pertemuan yang berarti rasa keingintahuan siswa terhadap kegiatan yang dilakukan sudah lebih tinggi. Hasil penilaian afektif siswa dapat dilihat pada tabel 4.

Tabel 4. Presentase nilai psikomotor

\begin{tabular}{|c|c|c|c|c|}
\hline \multirow[t]{2}{*}{ No } & \multirow{2}{*}{\multicolumn{2}{|c|}{ Siklus }} & \multicolumn{2}{|c|}{ Presentase } \\
\hline & & & Skor & Rata -rata \\
\hline 1. & Siklus 1 & $\begin{array}{l}\text { Pertemuan I } \\
\text { Pertemuan II }\end{array}$ & $\begin{array}{l}64,67 \% \\
76,17 \%\end{array}$ & $70,42 \%$ \\
\hline 2. & Siklus 2 & $\begin{array}{l}\text { Pertemuan I } \\
\text { Pertemuan II }\end{array}$ & $\begin{array}{l}80,10 \% \\
\quad 84,15 \%\end{array}$ & $82,12 \%$ \\
\hline
\end{tabular}


p-ISSN 2338-3240, e-ISSN 2580-5924

\section{5) Hasil Belajar Siswa}

Hasil Belajar siswa dapat dilihat dari hasil evaluasi setiap akhir siklus. Secara umum hasil belajar siswa yang diperoleh mengalami peningkatan. Selengkapnya dapat dilihat pada tabel 5 .

Tabel 5. Hasil belajar siswa

\begin{tabular}{llcc} 
No. & Penilaian & Siklus I & Siklus \\
II & & 71,73 & 80,00 \\
\hline 1. & Skor rata-rata & 8 & 10 \\
2. & Skor Tertinggi & 4 & 4 \\
3. & Skor Terendah & $71,73 \%$ & \\
4. & $\begin{array}{l}\text { Presentase daya } \\
\text { 80,80\% }\end{array}$ & & \\
& $\begin{array}{l}\text { serap klasikal } \\
\text { Persentase ketuntasan } \\
\text { belajar klasikal }\end{array}$ & $72,00 \%$ & $88,00 \%$
\end{tabular}

Berdasarkan tabel 3 tampak bahwa hasil yang diperoleh pada siklus I belum memenuhi syarat minimal yang ditentukan. Hal ini disebabkan siswa cenderung diam walaupun ada beberapa konsep yang tidak dipahami dan tidak mau bertanya baik kepada peneliti maupun dengan sesama anggota kelompoknya. Dalam mengerjakan tes pada setiap siklus, terlihat masih terdapat sejumlah siswa yang belum bisa mengerjakan tes dengan baik, khususnya dalam mengerjakan tes dalam bentuk pemahaman dan perhitungan.

Pada siklus II siswa menunjukan aktivitas lebih baik dari siklus I. Siswa lebih senang dan tertarik untuk belajar karena mereka lebih mudah memahami materi yang diajarkan, dan juga kegiatan pengamatan serta penyelidikan berhubungan dengan masalah yang mereka temui di kehidupan sehari-hari, sehingga lebih mudah bagi siswa untuk mengingatnya. Alasanalasan ini menunjukkan bahwa penelitian dengan menerapkan model pembelajaran Learning Cycle 5E dikatakan berhasil. Uraian di atas dapat dikatakan bahwa penggunaan model pembelajaran Learning Cycle $5 E$ dapat memberikan pengalaman kepada siswa, sehingga dapat meningkatkan hasil belajar fisika. Hasil spelaksanaan tindakan siklus II diperoleh ketuntasan belajar klasikal mencapai $88,8 \%$ dan daya serap klasikal $84,00 \%$ dari perolehan tersebut menunjukkan hasil lebih baik dari siklus I.

Pada tahap pertama model pembelajaran 5E yaitu tahap engagement (pembangkit minat). Tahap pertemuan pertama dimana peneliti menanyakan mengenai pengetahuan awal siswa dengan memberikan pertanyaan mengapa jejak kaki ayam lebih dalam dibandingkan dengan jejak kaki bebek? yang berhubungan dengan kehidupan sehari-hari. Pada tahap ini siswa mulai aktif dalam menjawab pertanyaan, hal ini dapat terlihat dari antusias semua siswa dalam menjawab. Hasil ini sesuai dengan penelitian Kulsum, dkk (2011) yang menyatakan bahwa pada tahap engagement (pembangkit minat) dapat membangkitkan semangat siswa dalam memulai pembelajaran dan membuat siswa lebih aktif dalam pembelajaran.

$$
\text { Selanjutnya tahap }
$$

exploration

(eksplorasi), pada tahap ini siswa berkelompok untuk melakukan ekperimen. Siswa menjadi lebih aktif sedangkan guru hanya mengarahkan siswa untuk dapat menemukan konsep yang dimaksud. Hasil ini sesuai dengan penelitian yang dilakukan oleh Nurjannah (2014), kelompok yang melakukan pengamatan melalui eksperimen hasilnya lebih baik dari kelompok yang menerima materi dari gambar karena melalui eksperimen siswa terlibat langsung dalam kegiatan untuk menemukan suatu konsep dan melibatkan lebih banyak indera. Kemudian dilanjutkan menyelesaikan permasalahan yang terdapat didalam Lembar Kerja Siswa (LKS).

Tahap selanjutnya adalah tahap explanation (penjelasan), pada tahap ini siswa akan memberikan perwakilan dari setiap kelompok untuk maju mempresentasikan hasil yang diperoleh pada tahap exploration. Siswa akan menjelaskan konsep dari ekperimen yang telah dilakukan dengan menggunakan bahasa mereka sendiri atau bahasa yang mereka pahami. Jika masih terdapat jawaban yang kurang tepat maka guru akan meluruskan jawaban siswa tersebut.

Tahap yang keempat yaitu elaboration (elaborasi) yang bertujuan agar siswa dapat menerapkan konsep yang baru saja mereka pelajari dalam situasi yang berbeda atau konteks yang berbeda. Pada tahap ini guru memberikan pertanyaan kepada siswa dan didiskusikan secara berkelompok. Siswa akan lebih mudah dalam menjawab pertanyaan karena mereka telah mengetahui konsep yang dipelajari. Selain itu, siswa akan mengetahui contoh penerapan dari konsep yang telah dipelajari.

Selama kegiatan diskusi berlangsung guru memantau jalannya diskusi, memberikan bimbingan serta motivasi agar siswa aktif terlibat dalam kegiatan pemecahan masalah di kelompok masing-masing [4]. Guru memberikan motivasi agar siswa aktif berdiskusi karena hasil pemikiran beberapa siswa akan lebih baik daripada hasil pemikiran satu siswa saja.

Tahap yang terakhir adalah tahap evaluation (evaluasi), pada tahap ini guru memberikan kuis atau teks. Dari nilai yang 
diperoleh siswa, terlihat perubahan hasil belajar siswa mengalami peningkatan.

Kelebihan dari model pembelajaran ini dibandingkan dengan model pembelajaran konvensional adalah keaktifan siswa. Karena dengan menggunakan model pembelajaran 5E siswa memiliki kesempatan untuk menyelidiki sendiri, menemukan konsep, dan menjelaskan konsep dengan bahasa yang lebih mereka pahami. Model pembelajaran 5E merupakan model yang menuntut aktifitas maupun kreativitas siswa dalam belajar diantaranya membuat siswa lebih termotivasi dalam bekerja sama [3]. Penggunaan model learning cycle dapat mempermudah belajar siswa karena mereka secara langsung berinteraksi dengan lingkungan untuk menganalisis fenomenafenomena perilaku sosial sehingga mereka dapat memahami konsep-konsep materi ajar sehingga tujuan pengajaran dapat tercapai [5].

Hasil yang diperoleh sama dengan hasil penelitian sebelumnya, yaitu terdapat peningkatan penguasaan konsep dan keterampilan proses antara kelompok siswa yang dibelajarkan dengan siklus belajar 5E [6]. Mengemukakan bahwa terdapat pengaruh penerapan model pembelajaran $5 \mathrm{E}$ terhadap hasil belajar siswa. Hasil penelitian yang menyatakan bahwa penerapan model pembelajaran $5 \mathrm{E}$ dapat meningkatkan kemampuan pemecahan masalah.

\section{KESIMPULAN}

Berdasarkan hasil penelitian dapat diambil kesimpulan, bahwa model pembelajaran Learning Cycle $5 E$ dapat meningkatkan hasil belajar fisika pada siswa kelas VIII SMPN Negeri 14 Palu. Hal ini dapat dilihat pada hasil belajar pada siklus I dan siklus II setelah menerapkan model pembelajaran Learning Cycle $5 E$ lebih tinggi dibandingkan hasil belajar semester tahun ajaran 2015/2016. Selain itu hasil belajar yang diperoleh sudah lebih besar daripada indikator ketuntasan yang dipersyaratkan.

\section{DAFTAR PUSTAKA}

[1] Dimyati dan Moedjiono. (1994) . Belajar dan Pembelajaran. Jakarta: Rineka Cipta.

[2] Erman,S. (2003). Strategi Pembelajaran Matematika Komtemporer. Bandung: JICA-UPI.

[3] Holijah. (2011). Peningkatan Pemahaman Konsep Fisika Melalui Model Pembelajaran Learning Cycle (LC) Pada Siswa Kelas VIIIC SMP Negeri 19 Palu. Skripsi Sarjana pada FKIP UNTAD Palu: Tidak diterbitkan.
p-ISSN 2338-3240, e-ISSN 2580-5924

[4] Lie, Anita. (2008). Cooperative Learning: Mempraktikkan Cooperative Learning di Ruang-Ruang Kelas. Jakarta: Gramedia.

[5] Simatupang, D. (2008). "Pembelajaran Model Siklus Belajar (Learning Cycle)". Jurnal Kewarganegaraan. vol 10(1), 62-70.

[6] Karim, L.A. (2012). Penerapan Model Learning Cycle Untuk Meningkatkan Penguasaan Konsep Getaran Dan Gelombang Pada Kelas VIII SMP 9 Palu. Skripsi Sarjana pada FKIP UNTAD Palu: Tidak diterbitkan. 